Second World War was not completed until 1948. For some years the trustees have been supported by substantial contributions from the British Exchequer $(£ 21,000$ in the current year) and payments from the Royal Greenwich Observatory, but this uncertain method of support has now been replaced by direet support from the Science Research Council. For a seven year period the full cost of maintaining and operating the observatory will be paid by the S.R.C., excopt for a small contribution from the Radcliffe Trustees Astronomy Fund.

The telescope is important, because the southern skies are relatively unexplored, and contain vitally important objects such as the Magellanic Clouds and the centre of the galaxy. For some time there have been plans for a new telescope in Australia, to be called the Southern Hemisphere telescope, but financial difficultics have so far prevented it from being built. There have successively been suggestions that either the British or the American governments might be prepared to support the building of the new telescope. At the moment discussions are apparently in progress between the Australian and British governments, but so far no decision has been reached.

\section{Editors United}

AT a conference of editors of biological journals in Amsterdam on April 11-12, the decision was taken to set up an Association of European Editors of Biological Periodicals. The association hopes to become a channel for communication and co-operation between editors, and hopes that the result will be greatcr efficiency. Among the issues of importance to the journals raised at the conference was that of copyright; journals are increasingly concerned at the photocopying of printed text, but there is also the question of whether there should be a uniform code of practice in the reproduction of journal articles in other sccondary publications. A working party under Dr. J. E. Treherne (Cambridge) will study this matter. Another working party under Professor K. Faegri (Bergen) is embarking on a comparative study of the machinery used by various journals for refereeing original communications. There is also to be an attempt to devise an internationally valid style book for biological journals.

The president of the new association is Professor F. A. Stafleu of the Instituut voor Systematische Plantkunde, Utrecht. The secretary is Dr. J. Bures of the Institute of Physiology of the Czechoslovak Academy of Sciences. It is expected that the total membership of the association may eventually include 200 or more European biological journals. It is planned that there shall be general assemblies of the association at intervals of three years.

\section{Vanishing Phenomenon}

THE backlog of manuscripts awaiting publication in Nature has becomo such a persistent but variable entity that it may be thought to constitutes a phenomonon in its own right. From time to time it has been spoken of as if it were a joke, although most of those concerned with it-and particularly authors of manuscripts-say quite properly that it is not a joke at all.
For this reason, the accompanying histogram may be at once intercsting and comforting. It shows the numbers of manuscripts in the Nature office at the beginning of each month since the beginning of 1966 . These figures do not include the manuscripts already at the printers. This omission is, however, almost exactly compensated for by the inclusion in the monthly census of manuscripts then with referees, many of which are destined to be returned to their authors (in white for April 1967). The fact that the Nature backlog was of the order of 500 manuscripts at the beginning of April-it is less now-should be set against the fact that during the past 9 months, the rate of publication in Nature has bcen 299 manuscripts a month. It is on this basis that the backlog is expected to disappear before the seasonal demand on space reaches its pcak at this end of the academic year.

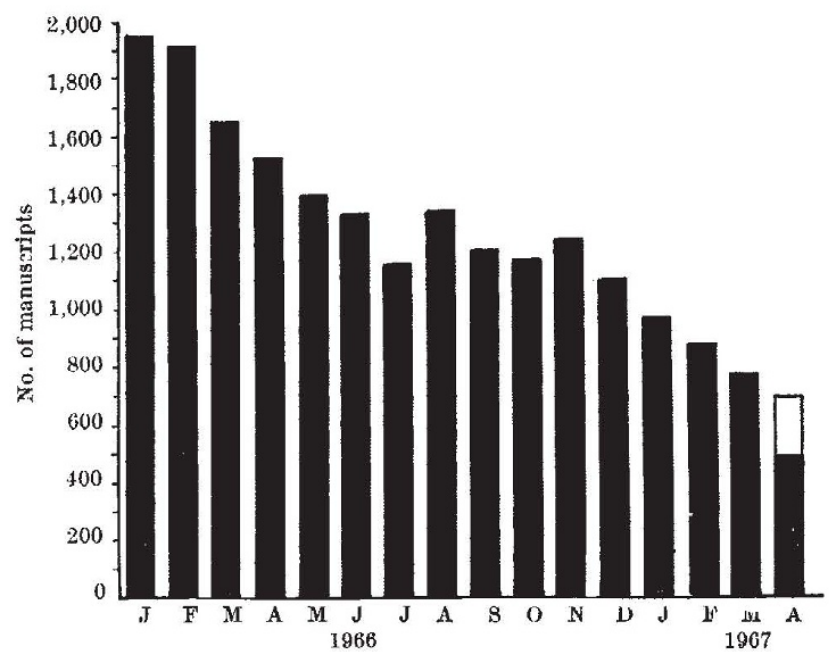

\section{More Enzyme Molecules}

DR. L. N. Jounson writes:

For some years knowledge of the three-dimensional structure of proteins has becn limited to two structures -myoglobin and lysozyme. Suddenly in the past few months, the total has increased from two to five structures. At the meeting of the Institute of Physics X-ray Analysis Group in Oxford last week, the structures of the three new proteins-ribonuclease $A$, ribonuclease $S$ and alpha-chymotrypsin-were reported. It was also clcar that high resolution work on carboxypeptidase $A$ is progressing well, that more detailed comparisons of human and horse deoxy-haemoglobin with horse oxyhacmoglobin are proving fruitful, and that good low resolution studies on carbonic anhydrase and beta-lactoglobulin have been carried out. Progress was also reported in the location of iron atoms in ferredoxin and in the study of the elusive structure of insulin. On other biological materials, there were encouraging reports of X-ray diffraction studies on RNA, viruses, polysaccharides and lipids. This meeting will no doubt be recognized as a historic landmark, and it was particularly pleasing to have at the confercnce Professors J. D. Bernal and Dorothy Hodgkin, who thirty-three years ago had taken the first X-ray diffraction photographs of a protein.

The most remurkable paper was the report from Dr. Tavid Blow of the Medical Research Council in Cambridge on the structure of the protcolytic enzyme 